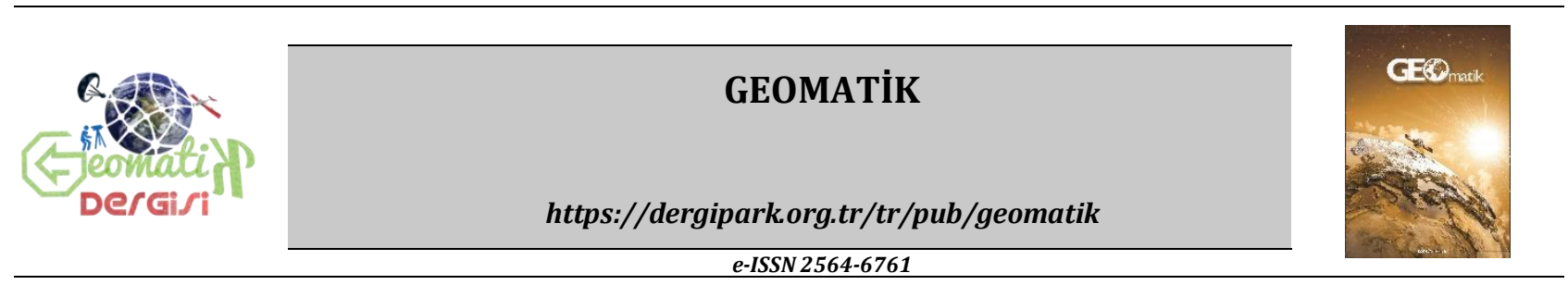

\title{
Yapı Ruhsatlandırmadan Kat Mülkiyetine Giden Süreçlerin Dijitalleştirilmesi: Mevcut Durum Analizi ve Öneri
}

\author{
Doğuş Güler*1, Tahsin Yomralığlu1 \\ 1İstanbul Teknik Üniversitesi, Inşaat Fakültesi, Geomatik Mühendisliği, İstanbul, Türkiye
}

\author{
Anahtar Kelimeler \\ Yapı Ruhsatı \\ Yapi Kullanma İzni \\ Kat Mülkiyeti \\ Yapı Bilgi Modellemesi (BIM) \\ Coğrafi Bilgi Sistemleri (CBS)
}

\begin{abstract}
ÖZ
Hızlı nüfus artışıyla birlikte yaşam alanlarındaki talebin karşılanması için birçok yeni yapı inşaatı yapılmakta ve mevcut yapılar yenilenmektedir. Arazi parsellerinde oluşan bu güncellemeler için yapı ruhsatı ve yapı kullanma izin belgesi alınması zorunludur. Günümüzde yapı ruhsatı süreçleri genellikle iki boyutlu (2B) proje dosyaları veya kâğıt çıktıları kullanılarak manuel olarak gerçekleştirilmektedir. Diğer bir yandan yapının tamamlanmasıyla ortaya çıkan kat mülkiyeti kavramıyla parsel üzerindeki cins değişikliklerine istinaden ulusal kadastro veri tabanının da güncellenmesi gerekmektedir. Mevcut durumda mülkiyet haklarının ve fiziksel bileșenlerinin 2B grafikler ile tam olarak betimlenememesinden kaynaklanan problemler ortaya çıkabilmektedir. Bu bağlamda, çalışmada Türkiye'deki yapı ruhsat ve kat mülkiyeti süreçlerinin daha nitelikli hale getirilebilmesi için Yapı Bilgi Modellemesi (BIM) ve Coğrafi Bilgi Sistemleri (CBS) veri modellerinden faydalanılan bir iş çerçevesi önerisinde bulunulması amaçlanmıştır. İstanbul'daki ilçe belediyelerinin internet siteleri incelenerek yapı ruhsatı süreçlerinde dijital veri kullanımı ile ilgili değerlendirme yapılmıștır. Çalıșmanın sonuçları yapı ruhsatı süreçlerinin elektronik ve üç boyutlu (3B) dijital yapı modelleri kullanılarak gerçekleştirilmesine ilişkin olarak istenilen düzeyde olmadığını göstermektedir. Ancak dijital yapı ruhsatı süreçlerinin hayat geçirilebilmesi için özel ve kamu sektörü anlamında önemli bir potansiyel olduğu da göz ardı edilmemelidir. Bu bağlamda Türkiye'de ileriye dönük olarak üretilecek planlama ve stratejilerde kullanılabilecek bulgular aktarılmıștır.
\end{abstract}

\section{Digitalization of Processes from Building Permit Issuing to Property Ownership: Current Situation Analysis and Proposal}

\author{
Keywords \\ Building Permit \\ Occupancy Permit \\ Property Ownership \\ Building Information \\ Modelling (BIM) \\ Geographic Information \\ Systems (GIS)
}

\begin{abstract}
Because of the rapid population growth, to meet the demand in the living spaces, many new buildings are being constructed and existing buildings are being renewed. Getting a building permit is mandatory for these updates that occur in the land parcels. Nowadays, the building permit processes are manually carried out by using two dimensional (2D) project files and paper outputs in general. On the other hand, the national cadastral database should be updated with respect to land-use conversions due to the property ownership notion that arises out of the completion of construction. Currently, there are problems related to this issue because property rights and their components cannot be accurately represented by using $2 \mathrm{D}$ graphics. In this context, this paper aims to propose a framework that benefits from data models formatted by using Building Information Modelling (BIM) and Geographic Information Systems (GIS) techniques in order to improve the building permit procedures in Turkey. The evaluation with regard to the use of digital data in building permit processes is carried out by examining the websites of municipalities in Istanbul, Turkey. The results show that building permit processes are not at the expected level with regards to electronic submission and the use of three dimensional (3D) digital building models. However, there is an important potential for achieving digital building permit procedures in terms of private and public sectors. In this direction, the findings that could be used for forward planning and strategies in Turkey are presented.
\end{abstract}




\section{GíRiş}

Son yirmi yıllık süre zarfında akıllı șehir (smart city) kavramı bilimsel literatürde ve uluslararası politikalarda oldukça popüler hale gelmiştir ve bu popülerlik de gün geçtikçe artmaktadır. Akıllı şehir; sürdürülebilir ve daha yeşil bir şehir yaratmak için ve yaşam kalitesini artırmak adına, rekabetçi ve yeniliğe açık şekilde yeni teknolojileri kullanarak insanları, bilgiyi ve şehir bileşenlerini birbirine bağlayan, yüksek teknolojiye adapte olabilen ve aynı zamanda gelişmiş bir şehir olarak tanımlanabilir (Bakici ark., 2013). Bununla birlikte akıllı şehirler öncelikle lokasyon, mekân ve diğer konumsal bilgileri yerel idarelere, vatandaşlara ve işletmelere onların aktivitelerini organize ederek ulaştıran konumsal olarak olanaklı (spatially enabled) şehir özelliğine sahip olmalıdır (Williamson ark., 2011).

Artan şehirleşme ve iklim değişikliği gibi etkenler hükümetleri vatandaşlarına daha yaşanabilir, nitelikli ve çevresel açıdan refah seviyesi yüksek bir yaşam ulaştırabilmek için karmaşık stratejilere adapte olmaya zorlamaktadır. Bu stratejiler yaşam alanıyla ilgili hizmetleri, altyapıyı ve çevresel unsurları içermektedir. Bu bakış açısıyla da şehirlere ilişkin akıllı sürdürülebilir kalkınma (smart sustainable development) önemli hale gelmektedir (Macke ark., 2019). Bu konuyla ilişkili olarak, yaşam alanlarında gerçekleştirilen yapı inşaatlarının kontrollü ve nitelikli olarak gerçekleştirilebilmeleri için kanun ve yönetmeliklerde belirtilen unsurlara ilişkin kontrollerin yapılması büyük öneme sahiptir.

Şehirlerdeki nüfus artışından dolayı birçok ülkede yeni yapıların inşa edilmesi için artan bir talep bulunmaktadır. Tüm bu inşaatlara başlanabilmesi için yapı ruhsatı (building permit) alınması zorunludur. Bu durumla ilişkili olarak yönetimler akıllı inşa edilmiş çevreyi (smart built environment) başarılı bir şekilde hayata geçirebilmek için yapı ruhsatı süreçlerinin iyileştirilmesinin yollarını aramaktadır. Çok sayıda düzenleyici birim hem yapı ruhsatı süreçlerinde hem de yapı kullanma izni süreçlerinde rol almaktadır. Bu nedenle bu süreçler özellikle büyük şehirlerde oldukça karmaşık hale gelmektedir. Yapı ruhsatı süreçleri yaygın olarak yapı tasarımının ve inşaat sürecinin yürürlükteki yasa, yönetmelikler ve imar planlarına uygun olup olmadığının kontrolünden oluşmaktadır. Ancak bu süreçler genellikle prosedürlerin şeffaf olmaması, fazlaca evrak işinin gerçekleştirilmesi ve yavaş inceleme yöntemlerinden kaynaklanan problemlere sahiptir (Malsane et al., 2015; Shahi et al., 2019).

$\mathrm{Bu}$ bağlamda, yapı ruhsatı süreçlerinin dijitalleştirmesi ve otomatikleştirilmesi bahsedilen olumsuzlukların önüne geçilebilmesi için son zamanlarda dikkat çeken araştırma konularından biri haline gelmiştir. Sözü edilen yaklaşım konumsal veri modellerinden ve uluslararası standartlardan yararlanılmasını içermektedir. $\mathrm{Bu}$ model ve standartlara dünya genelinde yaygın olarak kullanılan CityGML ve IFC örnek olarak gösterilebilir (Macit İlal ve Günaydın, 2017; Noardo et al., 2019; Olsson et al., 2018). Bu anlamda Türkiye'deki yapı ruhsatı süreçlerinin iyileştirilmesi ve diğer ülkelerdeki gelişmelere adapte olunabilmesi büyük önem arz etmektedir. Yapı ruhsatı süreçlerinin otomatikleştirilmesine yönelik olarak gerçekleştirilen bir literatür araştırmasında Türkiye'deki araștırmaların diğer ülkelere göre oldukça az olduğu saptanmıştır (Aydın ve Yaman, 2018).

Diğer bir yandan üç boyutlu (3B) şehir modellerinin üretilmesine yönelik dünya genelinde artan bir ilgi bulunmaktadır. Oluşturulan bu modeller yönetici ve karar vericilere enerji talebi tahmini, afet yönetimi ve vergilendirme ile gayrimenkul değerleme gibi birçok farklı konuda destek olmaktadır (Filip Biljecki et al., 2015). Bu durumla ilişkili olarak dijital kent modellerinin oluşturulması bağlamında özellikle metropollerdeki yapılar son on yıllık süre içerisinde yaygın bir şekilde 3B olarak betimlenmektedir. Mimarlık, mühendislik ve inşaat (AEC) firmaları yoğun bir şekilde yapıların yapı bilgi modellemesi (BIM) teknikleri kullanılarak 3B ve dijital olarak modellenmesiyle ilgilenmektedir. BIM, son yıllarda gösterdiği gelișmeyle modern AEC sektörü için vazgeçilmez bir iş süreci haline gelmiştir ve geleneksel bilgisayar destekli tasarımın (CAD) yerini almaktadır. Örneğin; yayımlanan bir rapora göre İngiltere'de BIM kullanımı 2011 yılında sadece \%13 iken 2018 yılında bu oran \%60'ın üzerinde bir artış göstererek \%74'e çıkmıştır (NBC, 2018). Türkiye'de gerçekleştirilen bir araştırma sonuçlarına göre ise katılım gösterenlerin \%54'ü projelerinde BIM kullandıklarını ifade etmişlerdir (BIMgenius, 2018). Bahsedilen istatistikler BIM'in kullanımının ve kazandığı önemin gittikçe artış gösterdiğine işaret etmektedir.

BIM iyi bir şekilde adapte edildiğinde, daha yüksek kalitede yapılar üreten bütünleşik tasarımı ve inşaat sürecini düşük maliyet ve azaltılmış proje süresiyle mümkün hale getirmektedir (Teicholz ark., 2018). BIM temelli üretilen modeller daha öncelerde sadece betimleme amaciyla üretilmelerine rağmen günümüzde yapılarla ilgili farklı analizlerin gerçekleștirilmesi amacıyla ve aynı zamanda kent veya ulusal ölçekteki konumsal veri altyapılarıyla entegrasyon için kullanılmaktadır. Böylece akıllı inşa edilmiş çevrenin dijital dönüşümü üretilen dijital ikiz (digital twin) şehirler aracılığıyla $3 \mathrm{~B}$ kent modellerinden önemli ölçüde faydalanmaktadır. Bahsedilen modeller uzman görüşlerine ve kullanım amacına bağlı olarak değişik platformlarda farklı teknikler kullanılarak oluşturulmaktadır (Eriksson et al., 2020). Ancak günümüzde 3B kent modellerinin üretimi karmaşık yaşam alanlarında zorlu bir süreçtir. Bununla birlikte oluşturulan konumsal veri modellerinin güncel tutulması şehirlerde gerçekleşen çok sayıda değişiklik nedeniyle gün geçtikçe zorlu hale gelmektedir. Bu nedenle 3B kent modellerinin hem üretimine hem de güncel tutulmasına katkı sağlayacak iş akışları önem arz 
etmektedir. Bu bağlamda Türkiye'de 3B şehir modellerini içeren konumsal veri altyapılarını tam anlamıyla elde etmek için etkili iș çerçevelerine ihtiyaç duyulmaktadır.

Bir diğer önemli konu ise temel konumsal veri setlerinin oluşturulmasına, ekonomilerin dijitalleştirilmesine ve akıllı sürdürülebilir şehirlerin mümkün kılınmasına önemli katkı veren arazi idare sistemleridir (Rajabifard, 2014). Bu sistemlere ilişkin işlemler genellikle iki boyutlu (2B) ve kâğıt tabanlı kayıtlarla gerçekleştirilmekte ve parsellerin 2B dijital betimlemelerini olanaklı kılmaktadır. Ancak sosyal eşitsizlik, kentleşme ve dijital dönüşüm gibi toplumla ilgili gerçekleșen önemli olaylarla başa çıkabilmek için arazi idare sistemlerinin 3B taşınmaz birimlerinin kullanılması bağlamında yeniden yapılandırılmasına gereksinim duyulmaktadır (Kalogianni et al., 2020). Bu konuyla ilgili olarak literatürde birçok çalışma yer almaktadır (Aien et al., 2013; Ho et al., 2013; Rajabifard et al., 2018). Bu bağlamda karmașık ve çok katmanlı yapılardaki mülkiyet haklarının dijital olarak gerçekçi ve detaylı olarak betimlenmesi ile kayıt altına alınması bir gereklilik haline gelmektedir. Bu dijital dönüşümün BIM teknikleriyle üretilen yapı modelleriyle gerçekleştirilmesi önemli bir seçenek olarak araştırılmaktadır (Oldfield et al., 2017). Literatürde Türkiye'deki arazi idaresi ve mülkiyet haklarının betimlenmesiyle ilgili çalışmalar da yer almaktadır (Alkan ve Polat, 2017; Çağdaş, 2013). Bu anlamda Türkiye'de 3B arazi idare sistemlerine ilişkin dönüşümün etkili bir şekilde gerçekleştirilebilmesi için faydalı iş çerçevelerine ihtiyaç bulunmaktadır.

Aktarılan bilgilere göre yapı ruhsatı ve kat mülkiyeti süreçlerinin dijitalleştirilmesi dünyada yoğun bir şekilde araştırılmaktadır. Örneğin, yakın zamanda birçok Avrupa ülkesinden araştırmacının yer aldığı dijital yapı ruhsatı süreçleri için geliştirilecek araçların farklı ülkelerde test edilmesine yönelik bir ağ kurulmuştur (https://3d.bk.tudelft.nl/projects/eunet_bp/). Bu çalışmada da mevcut yapı ruhsatı ve kat mülkiyeti süreçlerinin Türkiye'de iyileștirilmesine yönelik bir yaklaşım önerisinde bulunulması amaçlanmıştır. $\mathrm{Bu}$ yaklaşım dijital yapı modellerinin hem yapı ruhsatı süreçlerinde hem de mülkiyet haklarının temsilinde kullanılmasını içermektedir. Bunun yanı sıra inşa edilmiş diğer bir deyișle uygulanmış (as-built) dijital yapı modellerinin 3B şehir modellerinin güncellenmesinde de kullanılması yaklaşım önerisinde yer almaktadır. Bu bağlamda Türkiye için önerilen yaklaşım yazarların bilgisine göre literatürdeki ilk çalışmalardan birisidir ve bu nedenle önemini arttırmaktadır. Yapı ruhsatı süreçlerinde dijital veri kullanımı bağlamında mevcut durumu incelemek adına yoğun inşaat işlerinin gerçekleştiği İstanbul ilinin ilçelerindeki belediyelerin internet siteleri incelenmiştir. Yapılan değerlendirmeler soncunda e-devlet (e-government) dijital dönüşümü kapsamında da ülkeye ekonomik ve işlevsel açıdan nitelik kazandıracağı düşünülen önerilerde bulunulmuştur.

\section{ARAŞTIRMA ARKA PLANI}

\subsection{Yapı Ruhsatı ve Yapı Kullanma İzni Süreci}

Bir arazi parselinde inşa edilecek her bir yapı projesi kanunlar ve yönetmeliklerle belirlenen şartları sağlamak zorundadır. Bu durumla ilișkili olarak Türkiye'de 3/5/1985 tarihli ve 3194 sayllı İmar Kanunu'nun 21. Maddesi'nde belirtildiği üzere tüm yapılar için belediyeler veya valiliklerden yapı ruhsatı (yapı ruhsatiyesi) alınması zorunlu kllınmıștir (T.C. Resmi Gazete, 1985). Bununla birlikte yine aynı maddede mevcut yapılarda gerçekleștirilecek değişikler için yapı ruhsatı alınması şartı konulmuştur. Ancak imar yönetmeliklerine göre belirtildiği şekliyle yapının taşıyıcı unsurunu etkilemeyen tamir ve tadilatlar için yapı ruhsatı alınması zorunluluğu bulunmamaktadır. Yapı ruhsatı alma şartları ise aynı kanunun 22. Maddesi'nde açılanmıştır. Maddeye göre yapı ruhsatı alınabilmesi için belediyeler veya valiliklere eklerinde tapu, mimari, statik, elektrik ve tesisat projeleri ile kroki bulunan bir dilekçeyle başvurulması istenmektedir. Bu maddeyle birlikte yapı projelerinin sağlaması gereken şartlar İmar Kanunu ile 10/7/2018 tarihli ve 30474 sayılı Resmî Gazete'de yayımlanan 1 sayılı Cumhurbaşkanlığı Teşkilatı Hakkında Cumhurbaşkanlığı Kararnamesinde, Çevre ve Şehircilik Bakanlığının Teşkilat ve Görevlerini düzenleyen altıncı kısım üçüncü bölüm hükümlerine dayanılarak hazırlanan ve 3/7/2017 tarihinde 30113 sayılı Resmi Gazete'de yayımlanan Planlı Alanlar İmar Yönetmeliği'nde ayrıntılı olarak açıklanmaktadır (T.C. Resmi Gazete, 2017, 2018). Tablo 1 yapı ruhsatı başvurusunda istenen temel belgeleri göstermektedir.

Tablo 1. Türkiye'de yönetmelik ve kanunlara göre yapı ruhsatı alınabilmesi için gerekli belgeler

\begin{tabular}{|c|c|}
\hline Tapu & $\begin{array}{c}\text { Mekanik Tesisat } \\
\text { Projesi }\end{array}$ \\
\hline Plan ve ÇAP Belgeleri & Elektrik Tesisat Projesi \\
\hline İmar Durum Belgesi & Asansör Projesi \\
\hline Aplikasyon Krokisi & İnşaat Sözleşmesi \\
\hline Kot-Kesit Belgeleri & Muvafakatname \\
\hline İnşaat İstikamet Rölövesi & $\begin{array}{c}\text { Ruhsat ve Harç } \\
\text { Ücretleri }\end{array}$ \\
\hline Mimari Proje & Estetik Kurul Onayı \\
\hline Yapı Aplikasyon Projesi & Müteahhit Belgeleri \\
\hline $\begin{array}{c}\text { Zemin ve Temel Etüdü } \\
\text { Raporu }\end{array}$ & \begin{tabular}{c} 
Şantiye Şefi Belgeleri \\
\hline Statik Proje
\end{tabular} Yapı Denetim Belgeleri \\
\hline Peyzaj Projesi & $\begin{array}{c}\text { Ruhsat ve Harç } \\
\text { Ücretleri }\end{array}$ \\
\hline
\end{tabular}

İmar Kanunu'nda ayrıca yapı ruhsatı verilmesi için süre kısıtlamaları belirlenmiştir. Buna göre eğer belgelerde herhangi bir eksiklik veya yanlış bulunmuyorsa müracaat edilen kurum en geç otuz gün içerisinde yapı ruhsatı vermekle yükümlü kılınmıştrr. 


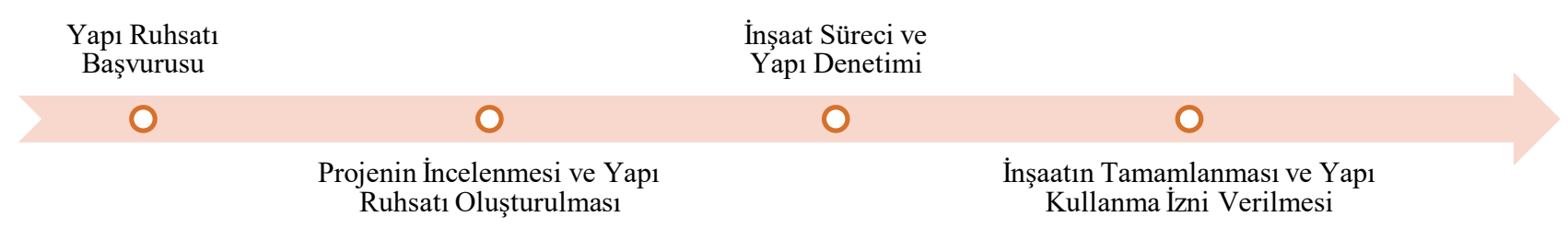

Şekil 1. Türkiye'de yapı projeleri için ruhsat, inşaat ve izin süreci

Eğer herhangi bir yanlışlık veya eksiklik bulunursa müracaat tarihinden en geç on beş gün içerisinde müracaat eden yetkiliye belirlenen eksiklik ve yanlışların bildirilmesi zorunlu kılınmıștır. Müracaat eden yetkiliye kendisine bildirilen yanlıș ve eksikleri gidererek yaptığı yeni başvuru tarihinden itibaren on beş gün içerisinde yapı ruhsatı verilmesi gerekmektedir. Kanunda belirtilen şartlara göre yapılan başvurularda müracaat edilen kurum yapı projesini mimari, statik, elektrik, peyzaj ve mekanik bakımdan yetkili birimleri dâhilinde incelemekte ve yapı ruhsatı verilip verilmeyeceğine karar vermektedir. Eğer proje kanunda ve yönetmelikte belirtilen tüm şartları eksiksiz olarak sağlıyorsa yapı ruhsatı hazırlanmakta ve ruhsatın müracaat eden kişiye tesliminin ardından yasal olarak yapı inşaatının başlayabilmesi mümkün olmaktadır.

İnşaatın başlamasından sonraki süreçte 29/6/2001 tarihli ve 4708 sayılı Yapı Denetimi Hakkında Kanun esaslarına göre her bir yapı projesi inşaatı süresince yapı ruhsatına göre inşa edilip edilmediğine dair bağımsız yapı denetim kuruluşları tarafindan denetlenmektedir (T.C. Resmi Gazete, 2001b). Bahsedilen yapı denetim kuruluşları eğer bir uygunsuzluk tespit ederse ilgili idarelere bilgi vermekle yükümlüdür. Yapı inşaatının tamamlanmasından sonraki süreçte İmar Kanunu'nun 30. Maddesi'nde belirtildiği üzere yapı kullanma izni alınması zorunludur. Yapı kullanma izni için yapılan müracaat kapsamında yapının ruhsat ve eklerine uygun olarak inşa edilip edilmediği incelenmektedir. Başvuru sürecinin en geç otuz gün içerisinde sonuçlandırılması gerekmektedir aksi halde yapının kullanılmasına izin verilmiş sayılmaktadır. Yapı kullanma izni bulunmayan yapılar İmar Kanunu'nun 31. Maddesi'ne göre elektrik, su ve kanalizasyon gibi kamu hizmetleri ile tesislerinden faydalanamazlar. Yapı kullanma izin belgesinin alınmasıyla birlikte yapı projesi sonuçlandırılmış olmaktadır. Şekil 1 Türkiye'de uygulanan yapı ruhsatı ve yapı kullanma iznine ilişkin temel işlem adımlarını göstermektedir.

Türkiye'de inşaat sektörü ülke ekonomisi açısından büyük bir paya sahiptir. Büyük kentlerin göç almasıyla birlikte artan nüfusun ihtiyacını karşılamak için birçok yapı inşa edilmektedir (Tekin ve Atabay, 2019). Bunun yanı sıra depreme ve doğal afetlere karşı dayanıksız yapılar kentsel dönüşüm kapsamında yıkılarak aynı parselde yeni yapılar inşa edilmektedir. Tüm inşaat süreçlerinde yapı ruhsatı alınması gerekmektedir. Türkiye İstatistik Kurumu (TÜİK) tarafından paylaşılan istatistiklere göre
Türkiye'deki son on iki yıllık sürede oluşturan yapı ruhsatı sayıları Şekil 2'de yer almaktadır (https://biruni.tuik.gov.tr/yapiizin/giris.zul).

Şekil 2'de görüldüğü üzere son on iki yılda oluşturulan toplam yapı ruhsatı sayısı herhangi bir yılda kırk binin altına düșmemiștir. Bununla birlikte 2010 ve 2014 ylllarında yüz kırk bine ulaşmıştır. 2017 yllında ise yüz altmış binin üzerinde yapı ruhsatı oluşturularak son on iki yılın en yüksek rakamına ulaşılmıştır. 2018 ve 2019 'da ise bir gerileme görülmektedir. Şekil 3'de ise son on iki yıllık süre zarfında Türkiye genelinde olușturulan yapı kullanma izin belgelerinin sayıları yer almaktadır. Son on iki yll içerisinde sadece 2008 yılında seksen binin altında yapı kullanma izin belgesi oluşturulmuştur. 2018 yllına doğru yükselen bir grafik görülmektedir.

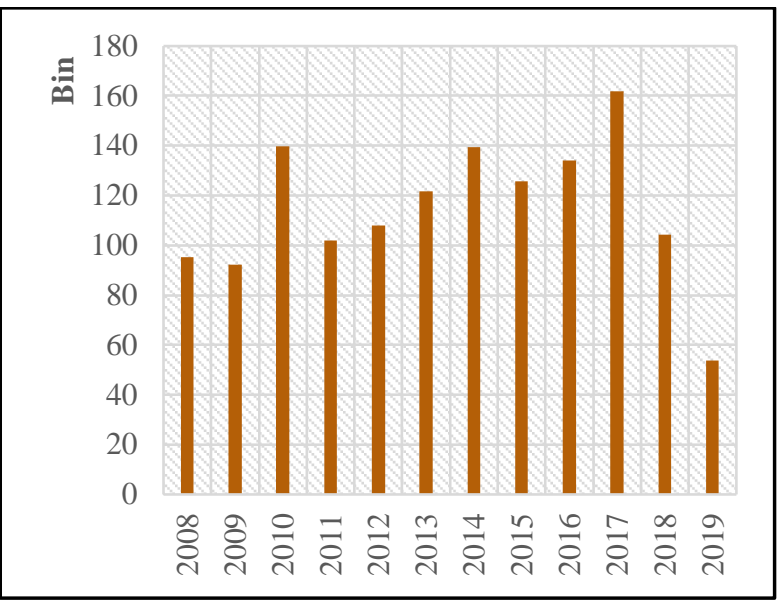

Şekil 2. Yıllara göre Türkiye'de oluşturulan yapı ruhsatı sayıları

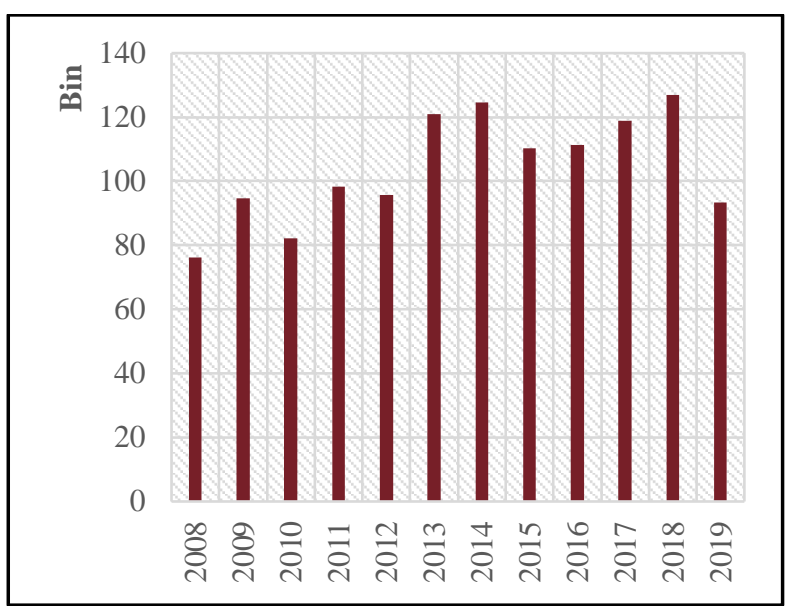

Şekil 3. Yıllara göre Türkiye'de oluşturulan yapı kullanma izin belgesi sayıları 


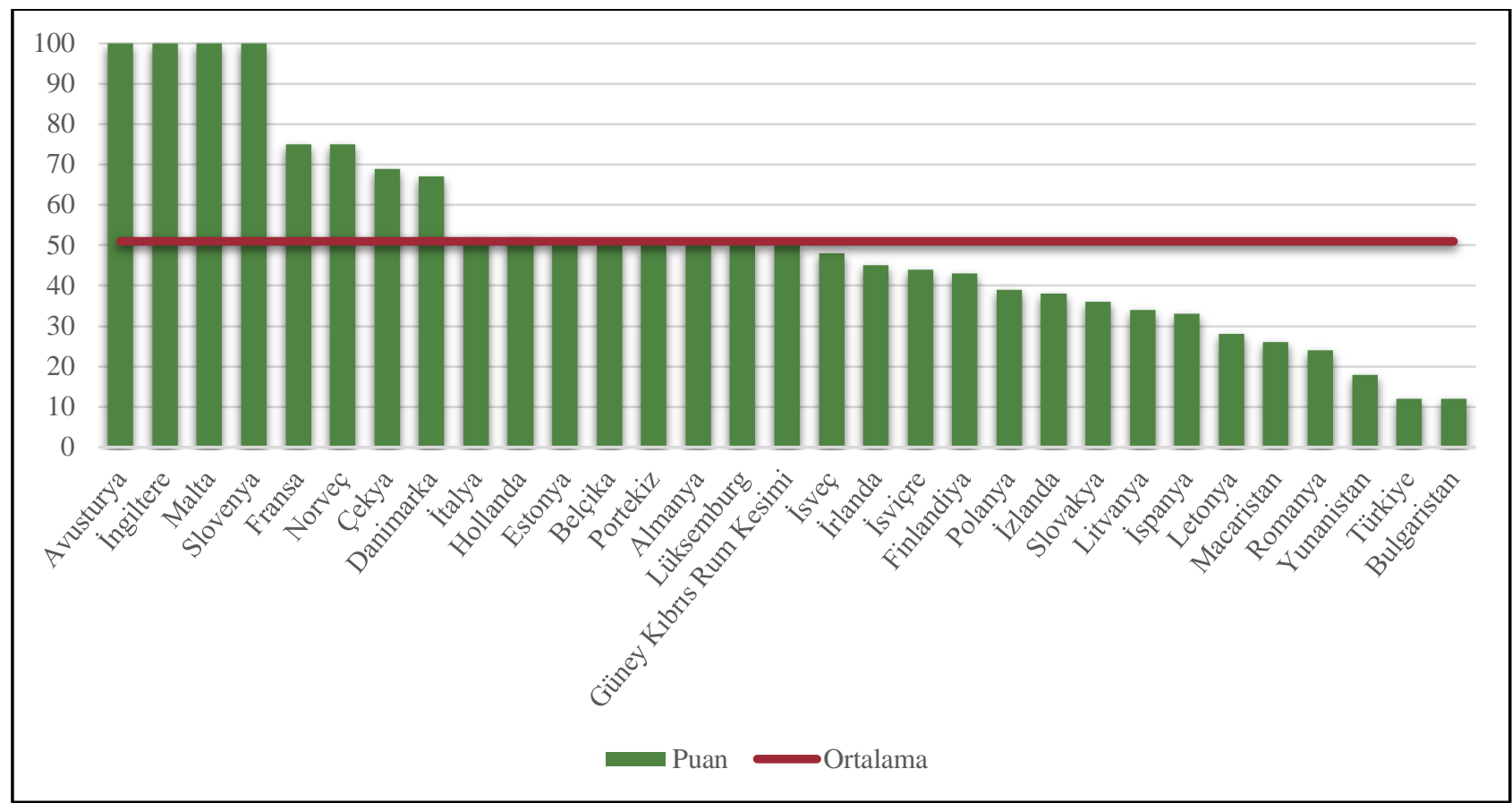

Şekil 4. AB ülkelerinin yapı ruhsatı süreci değerlendirme puanları (Capgemini, 2007)

Yapı ruhsatı sayısından farklı olarak 2018 yılında son on iki yılın en yüksek rakamına yüz yirmi binin üzerine çıkılarak ulașılmıştır. Her iki şekilden de anlaşılacağı üzere Türkiye'de yapı ruhsatı süreçleri gerçekleştirilen kamu hizmetleri arasında önemli bir yere sahiptir. Türkiye'deki yapı ruhsatı ve yapı kullanma izin belgesiyle ilgili kanun ve yönetmeliklerde başvuru ve inceleme sürecinin hangi veri formatları kullanılarak yürütüleceğine dair ayrıntılı bir esas yer almamaktadır. Bu nedenle başvurular yaygın olarak kâğıt çıktısı veya kompakt disk (CD) olarak kabul edilmektedir. Bununla birlikte projelerin uygunluğunun incelenmesi genellikle manuel olarak gerçekleștirilmektedir.

Avrupa ülkelerindeki mevcut yapı ruhsatı ve yapı kullanma izni süreçleri Türkiye'deki süreçle benzerlikler taşımaktadır. Mevcut duruma ilişkin yapılan değerlendirme sonuçlarına dayanarak proje alanındaki komşulara danışma gibi bazı adımlar Türkiye'deki mevcut süreçte yer almamaktadır.

Avrupa ülkelerinde benzer olarak yer alan temel yapı ruhsatı süreci adımları aşağıdaki şekilde siralanabilir (Meijer ark., 2002; Meijer ve Visscher, 2017; Noardo ark., 2019);

- Ön danışma,

- Yapı ruhsatı başvurusu,

- Proje alanındaki komşular ve diğer vatandaşlara danışma,

- Başvuru değerlendirmesi ve yönetmelik uyumluluğu kontrolü,

- Planlama kararının verilmesi,

- Inşaatın başlaması,

- İnşaat süresince proje sahasında denetim yapılması,

- İnşaatın tamamlanması ve ilgili idarelere durumun bildirilmesi,

- Sonuç incelemesi,
- Yapı kullanma izni verilmesi ve sürecin tamamlanmasi.

Avrupa ülkelerinde de yapı ruhsatı sürecinin iyileştirilmesi gerektiği düşüncesi yaygın olarak yer almaktadır. Bununla bağlantılı olarak en önemli gelișmelerden birisi 2002 yllında Avrupa Birliği (AB) tarafından açıklanan ve kamu hizmetlerinin daha etkin şekilde gerçekleştirilebilmesi için elektronik sistemin kullanılmasını öneren eylem planıdır. Plan, $\mathrm{AB}$ ülkelerinin bir an önce çevrimiçi sistemleri kullanıma almalarını vurgulamaktadır. 2005 yılında yeni bir eylem planı yayımlanarak e-devlet sistemlerinin yaygınlaşması ve zenginleştirilmesi amaçlanmiştır (Commission of the European Communities, 2002, 2006).

Mevcut durumda AB tarafindan yayımlanan son e-devlet eylem planı 2016-2020 yıllarını içermektedir (European Commission, 2016b). 2016 yılında $\mathrm{AB}$ tarafından yayımlanan değerlendirme raporuna göre ülkelerin e-devlet sistemine geçiște büyük gelișme kaydettikleri aktarılmıștır (European Commission, 2016a). Bu bağlamda $\mathrm{AB}$ aday ülkesi olarak Türkiye 2001 yllında bahsedilen projeye davet edilmiștir. Bu gelişmeyle birlikte Türkiye'de edönüşüm ile ilgili olarak acil eylem planları hazırlanarak proje hedeflerine ulaşılması için çalışmalar yapılmıştır. Ülkelerin mevcut yapı ruhsatı süreçlerini değerlendiren ve 2007 yllında yayımlanan rapora göre $\mathrm{AB}$ ülkeleri ve aday ülkelerin ortalaması $\% 51$ olurken Türkiye $\% 12$ puanla Bulgaristan ile son sıralarda yer almıştır (Şekil 4). Bu çalışma 2020 itibariyle yapı ruhsatı süreçlerinin $\mathrm{AB}$ ve aday ülkeler kapsamında değerlendiren, ulaşılabilir, en güncel istatistiki çalışmadır. İstatistikler oluşturulurken ülkeler, yapı ruhsatı sürecinde bilgilendirici bir internet sitesine sahip olunup olmadığı, başvuruların elektronik olarak yapılıp yapılamadığı ve bașvuru takibinin 
çevrimiçi olarak yapılıp yapılamadığına dair değerlendirilmiştir. Bahsedilen istatistik gerçekleștirildiği zamana göre fikir vermektedir.

Birleşmiş Milletler (UN) tarafından 2003 yılından itibaren ülkelerin e-devlet dönüşümünde hangi aşamada olduklarını değerlendirmek adına "edevlet gelissme endeksi" (E-Government Development Index) ve "e-katilım endeksi" (E-Participation Index) sıralamaları yayımlanmaktadır (United Nations, 2018). Şekil 5'de yer alan son on ylldaki istatistiklere göre Türkiye e-devlet gelişme endeksi sıralamasında 76. sıradan 2018 yılında 53. sıraya yükselmiștir. Benzer şekilde e-katılım endeksi sıralamasında ise 2008 yllında 78. siradayken 2018'de 37. sırada yer almıştır. Bahsedilen istatistikler kesin bir ölçümden ziyade ülkeleri mevcut durumlarına göre birbirleriyle karşılaștırmaktadır. İstatistiklerden, Türkiye'de e-devlet dönüşümü kapsamında önemli gelişme kaydedildiği ve e-devlet sisteminin vatandaşlar tarafından benimsediğine dair bir sonuca varılabilir. Günümüzde Türkiye'de 20162019 yıllarını içeren "Ulusal e-Devlet Strateji ve Eylem Planı" uygulanmaktadır (T.C. Ulaştırma ve Altyapı Bakanlığı, 2016).

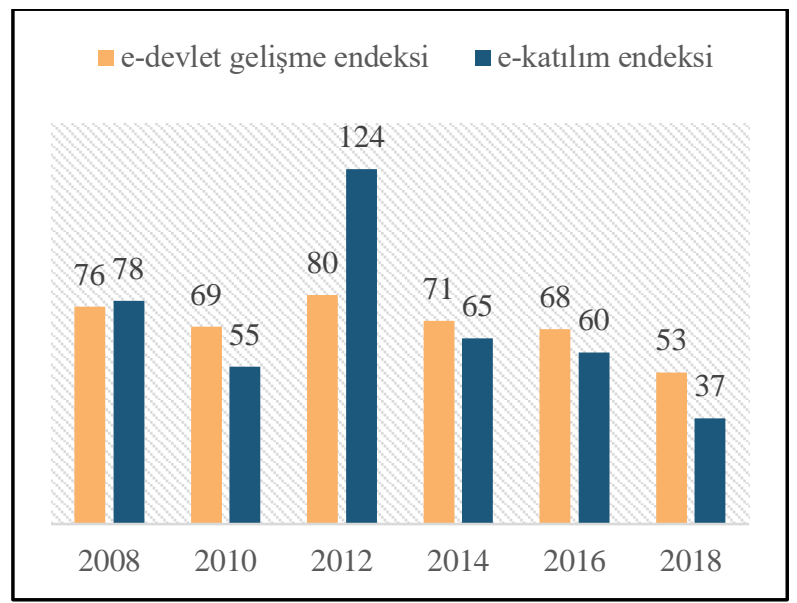

Şekil 5. Türkiye'nin yıllara göre e-devlet gelişmişliği ve kullanımına göre sıralaması

\subsection{Kat Mülkiyeti Süreci}

Türkiye'de arazilerin kullanımı ve düzenlenmesi anayasaya göre yürütülmektedir. Yapılan düzenlemeler sonucunda taşınmazların ölçülmesi ve kaydı ise Tapu ve Kadastro Genel Müdürlüğü (TKGM) tarafından gerçekleştirilmektedir. 4721 sayılı Türk Medeni Kanunu'nun 683. maddesinde mülkiyet hakkının içeriği tanımlanmıştır (T.C. Resmi Gazete, 2001a). Maddede hukuk düzeninin sınırları içerisinde olmak kaydıyla herhangi bir şeye malik olan kimsenin o şey üzerinde istediği şekilde kullanma, yararlanma ve tasarrufta bulunma hakkına sahip olduğu belirtilmiştir. Yine aynı kanunun 704. maddesinde ise taşınmaz mülkiyetinin konusu olarak aşağıdaki unsurlar aktarılmıștır;

- Arazi,
- Tapu kütüğüne ayrı bir sayfaya kaydedilen sürekli ve bağımsız haklar,

- Kat mülkiyeti kütüğüne kayıtlı bağımsız bölümler.

Türkiye'de kadastro 2B ve parsel tabanlı olarak TKGM tarafından 3402 sayll Kadastro Kanunu ve 5304 sayılı Kadastro Kanununda Değişiklik Yapılması Hakkında Kanun hükümlerine göre yürütülmektedir (T.C. Resmi Gazete, 1987, 2005). Birçok hakkın ve kısıtlamanın 2B olarak grafiksel temsili kayıt altına alınmaktadır. Bununla ilişkili olarak Türkiye'deki mülkiyet bilgilerinin etkin ve ișlevsel șekilde yönetilmesi için "Tapu ve Kadastro Bilgi Sistemi (TAKBIS)" kullanılmaktadır. Coğrafi/Arazi Bilgi Sistemi anlayışıyla çalışan sistem sayesinde taşınmazların bilgisayar ortamında hızlı ve güvenilir olarak takibi ile kontrolü sağlanmaktadır.

Bununla birlikte dünyada gerçekleştirilen 3B kadastro çalışmalarının gerisinde kalınmaması ve 2B grafiksel temsillerin mülkiyet haklarını yansıtmakta yetersiz kalmasından dolayı TKGM tarafindan "3 Boyutlu Şehir Modelleri ve Kadastro Projesi" başlatılmıștır. Projeye ait ön model olarak Ankara Gölbaşı ilçesi pilot bölge seçilerek modellemeler yapılmış ve internet üzerinden kullanıcılara sunulmuştur (http://3dtest.tkgm.gov.tr:44444/). Türkiye'de tamamlanan yapıların farklı bölümleri üzerinde bağımsız mülkiyet haklarının kurulması 634 sayılı Kat Mülkiyeti Kanunu hükümlerine göre gerçekleştirilir (T.C. Resmi Gazete, 1965). Kanunun 10. maddesinde belirtildiği üzere tapu tescilinde elektronik ortamda düzenlenen ve ilgili idare onaylı mimari proje planlarının kullanılması vurgulanmaktadır. Yine aynı maddede arazi parseline ilișkin cins değişikliği ișlemlerinde tescil bildiriminin yapı kullanma izin belgesini düzenleyen kuruma iletildiği ve ilgili kurumun yapı kullanma izin belgesi ve ek belgelerini tapu müdürlüğüne elektronik ortamda göndereceği aktarılmaktadır.

\section{DEĞERLENDİRME}

$\mathrm{Bu}$ bölümde Türkiye'deki yapı ruhsatı işlemlerinde dijital veri kullanılmasıyla ilişkili mevcut süreçle ilgili bir değerlendirme yapmak adına ülkedeki en yüksek yapı ruhsatı ve yapı kullanma izin belgesi payına sahip İstanbul ili seçilmiştir. Gerçekleştirilen işlem büyüklüğünü anlamak için TÜíK istatistiklerine göre İstanbul'da son on iki yılda oluşturulan yapı ruhsatı ve yapı kullanma izin belgesi sayıları Şekil 6 ve Şekil 7'de yer almaktadir.

Şekil 6'de görülebileceği üzere oluşturulan yapı ruhsatı sayısında Türkiye genelinde olduğu gibi 2018 ve 2019 yıllarında bir düşüş yaşanmıştır. Şekil 7'de ise 2008 yılından itibaren oluşturulan yapı kullanma izin belgeleri sayısında büyük bir artış gözlemlenmektedir. 


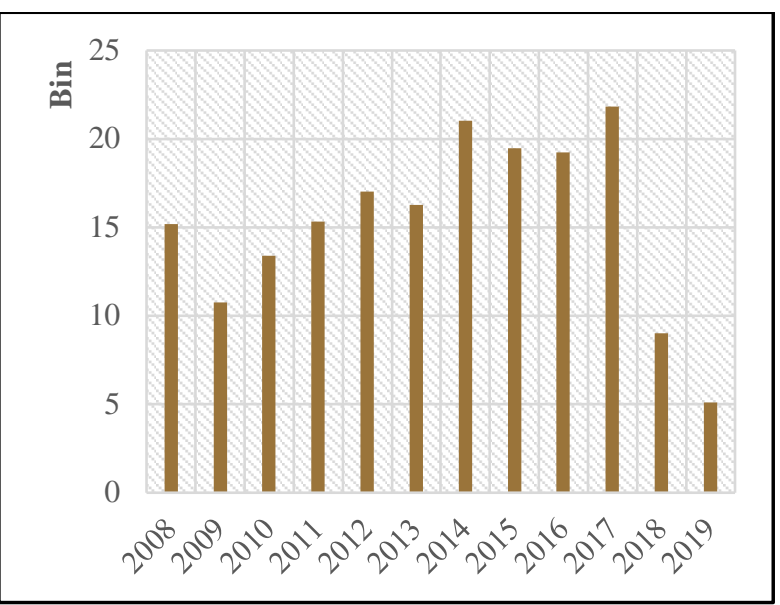

Şekil 6. Yıllara göre İstanbul'da oluşturulan yapı ruhsatı sayıları

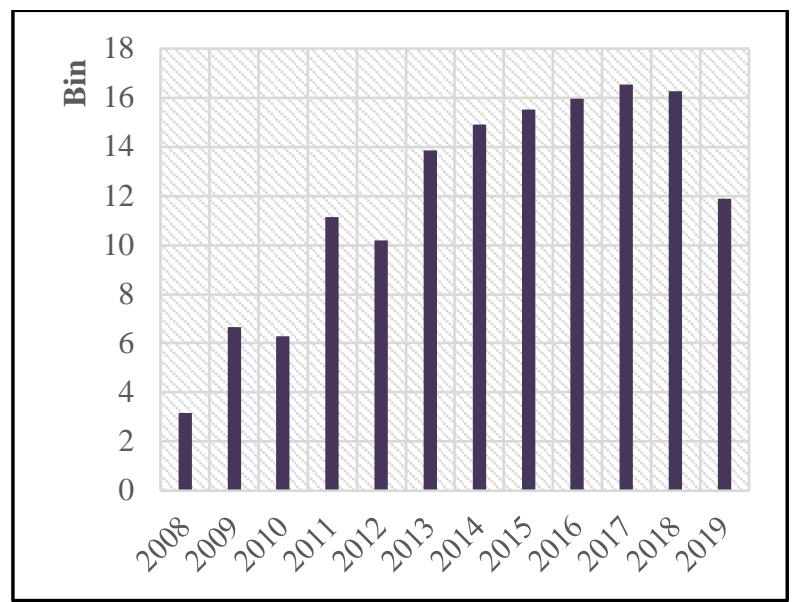

Şekil 7. Yıllara göre İstanbul'da oluşturulan yapı kullanma izin belgesi sayıları

Dünya'da yapı ruhsatı süreçlerinin iyileştirilmesi ve daha etkili hale getirilmesi için büyük çaba harcanmaktadır. Manuel olarak bașvuru belgelerinin incelenmesi yerine başvuru işlemlerinin çevrimiçi (online) olarak internet siteleri üzerinden gerçekleştirilmesi ülkelerin kamusal hizmetlerin dijitalleştirilmesi sürecinde amaçladıkları işlemlerden birisidir. $\mathrm{Bu}$ sistemin gelişmiş hali ise proje dosyalarının 3B olarak sisteme yüklenerek daha işlevsel yapı ruhsatı sürecine sahip olmaktır. Bu sayede kanun ve yönetmeliklerde belirtilen koşulların kontrolü daha gerçekçi ve anlaşılır şekilde yapılabilmektedir. Bu anlamda İstanbul'daki 39 ilçe belediyesinin internet sitesi incelenerek yapı ruhsatı ve yapı kullanma izni süreci dijital veri kullanımı ve elektronik başvuru açısından değerlendirilmiştir. TÜİK istatistiklerinden faydalanılarak hazırlanan, ilçelerin son beş yılda oluşturdukları yapı ruhsatı ve yapı kullanım izin belgesi sayıları Şekil 8 ve Şekil 9'da gösterilmektedir.

Şekil 8 ve Şekil 9'da görülebileceği üzere sırasıyla Esenyurt, Sancaktepe ve Küçükçekmece ilçeleri en fazla yapı ruhsatı ve yapı kullanma izin belgesi oluşturulan ilçeler olmuştur. Adalar ilçesi her iki belgeyi en az üreten ilçe olmuştur. Güngören ve Beşiktaş ilçeleri en az yapı ruhsatı oluşturan diğer ilçelerdir. Yapı kullanma izin belgesi oluşturmada Adalar ilçesini Beykoz ve Beşiktaş ilçeleri izlemektedir.

Sürecin değerlendirilmesi aşağıdaki başlıklar altında yapılmıştır;

- Yapı ruhsatı ve yapı kullanma izni sürecinde hangi işlemler internet sitesi üzerinden çevrimiçi olarak gerçekleştirilebilmektedir?

- Yapı ruhsatı alınması için belirtilen süre kaç gündür?

- Yapı kullanma izin belgesi alınması için belirtilen süre kaç gündür?

- Proje dosyası için istenen belirli bir dosya formatı bulunmakta mıdır?

- Proje dosyası 3B veri olarak istenmekte midir?

Tüm ilçe belediyelerine ait internet siteleri incelenerek yukarıda bahsedilen bașlıklara ilișkin Tablo 2 olușturulmuştur.

Gerçekleştirilebilen çevrimiçi işlemler bakımından 39 ilçeden 25'inin imar durum bilgisini sorgulama ve görüntüleme işlemini internet siteleri üzerinde sağladıkları görülmüştür.

Gaziosmanpaşa ve Pendik belediyelerinin yapı ruhsatı başvuru sürecini hızlandırmak ve iyileştirmek adına aynı internet sistem altyapısını kullanarak imar durumu bilgisinin görüntülenmesinin yanı sıra gerekli belgelerden olan inşaat istikamet ve kot kesit belgeleri taleplerinin çevrimiçi alınmasını ve aynı zamanda yapı ruhsatı başvurusunun da sisteme yüklenen belgelerle yapılabilmesini sağladıkları gözlemlenmiștir. Tüm belediyeler içerisinde yapı ruhsatı ve yapı kullanma izin belgesi başvuru sürecinin çevrimiçi olarak yapılabilmesini Bağcılar ve Beylikdüzü belediyelerinin sağladığı gözlemlenmiştir. Sürecin otomatikleştirilmesi için önemli bir yere sahip olan projelerin dosya formatına dair herhangi bir belediyenin özellikli bir format istemediği görülmüştür. Aynı zamanda 3B veriler kullanılarak gerçekleştirilebilen gelişmiş yapı ruhsatı süreci için incelenen başlığa ilişkin olarak herhangi bir belediyenin internet sitesinde gerekli proje verilerinin $3 \mathrm{~B}$ olup olmayacağına dair bilgiye ulașılamamıștır. Sürecin değerlendirilmesine dair diğer başlıklardan ikisi sürecin süreleriyle ilgilidir. Bu anlamda Adalar belediyesinin diğer kurumlardan istenen belgeler dolayısıyla daha geniş zaman aralığına sahip olduğu gözlemlenmiştir. Bununla birlikte ilçe belediyelerinin yapı ruhsatı sürecinin hızlandırılması için kendi bünyelerinde hizmet standartları belirledikleri görülmüştür. Bu durumla ilişkili olarak diğer belediyelerin İmar Kanunu'nda belirtilen yasal sürelerin altında zaman aralığında yapı ruhsatı süreçlerini tamamlamayı amaçladıkları açıkça görülmüştür. 


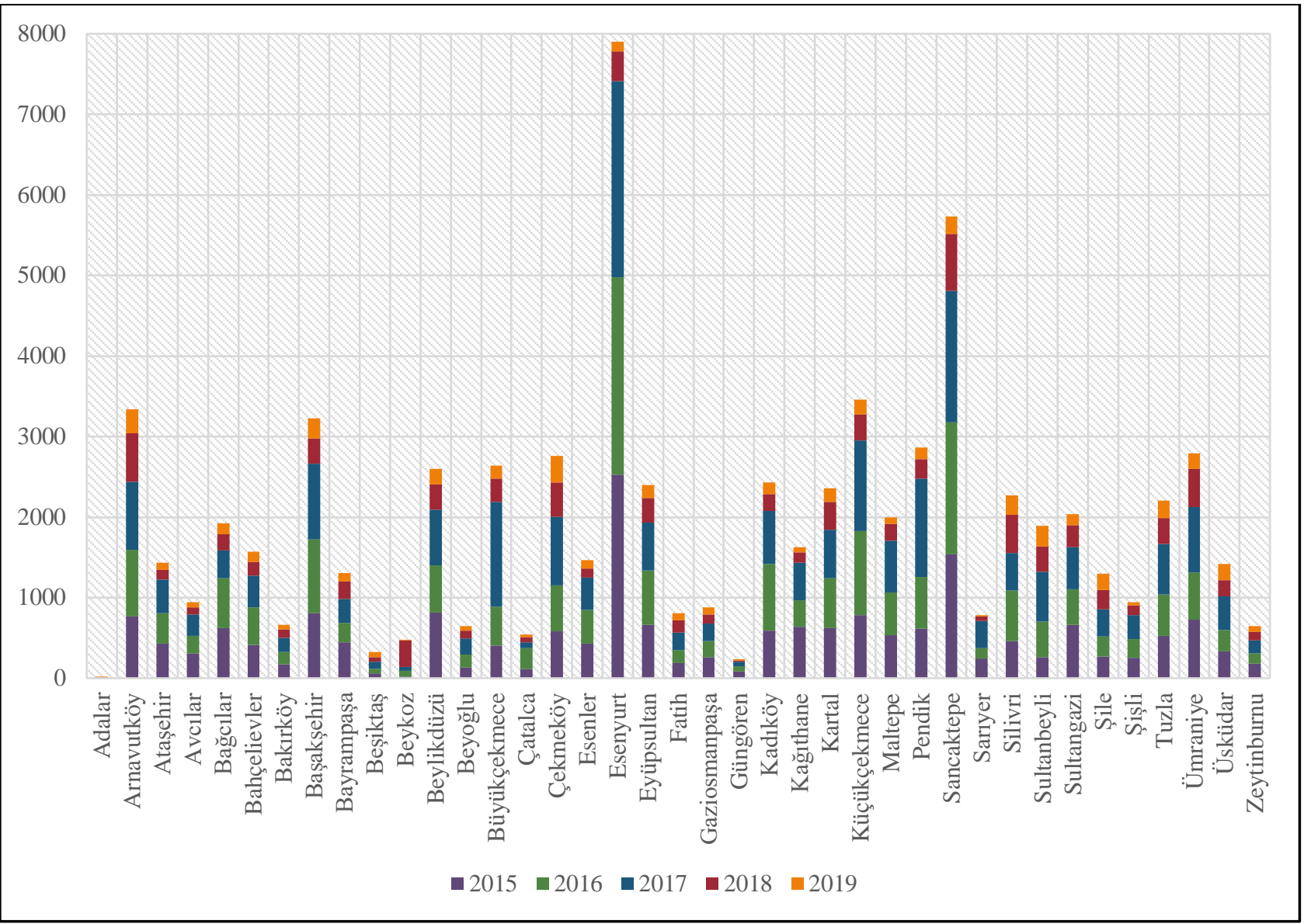

Şekil 8. Yıllara göre İstanbul ilçelerinde oluşturulan yapı ruhsatı sayıları

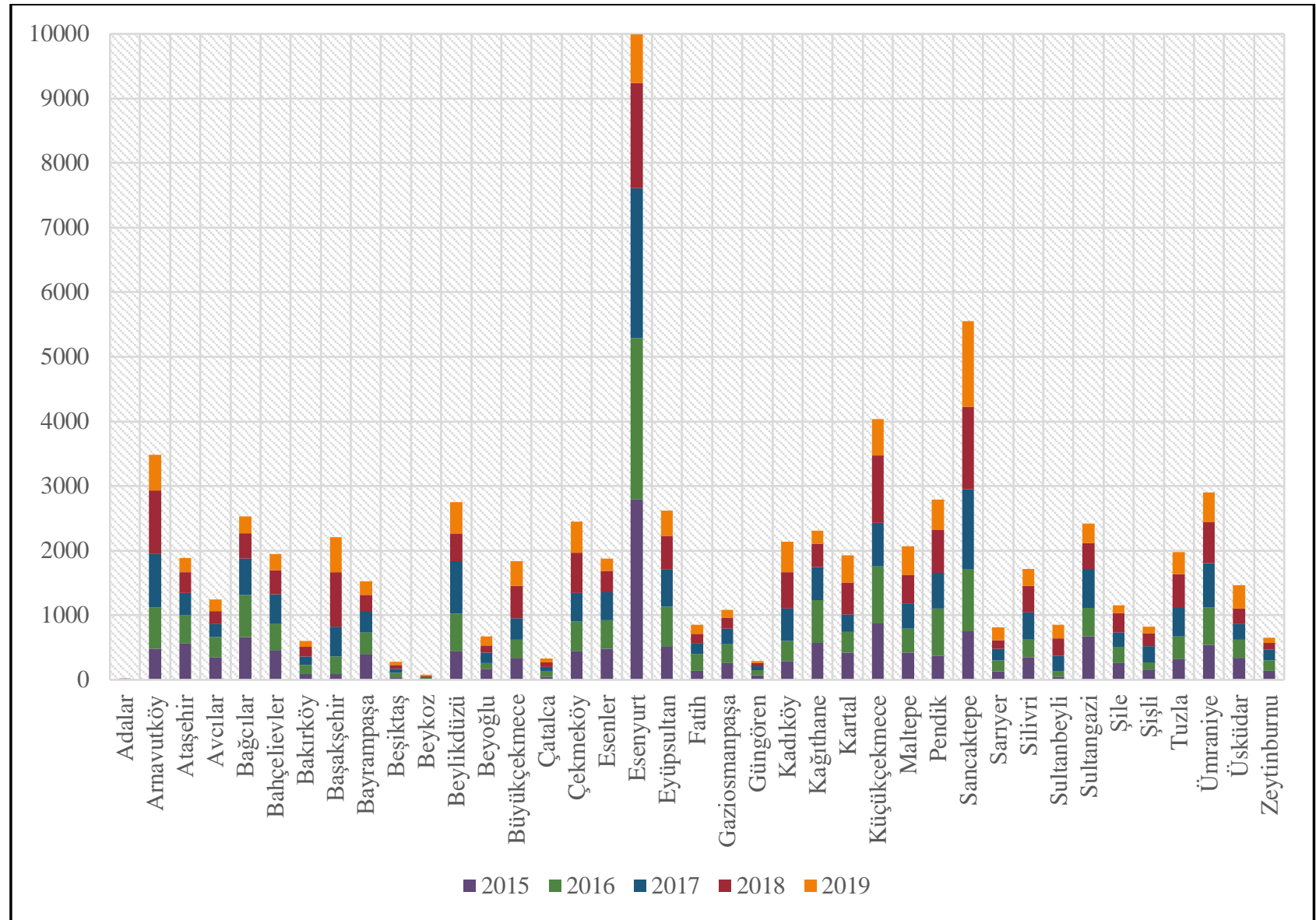

Şekil 9. Yıllara göre İstanbul ilçelerinde oluşturulan yapı kullanım izin belgesi sayıları 
Tablo 2. İstanbul ilçe belediyelerinin internet sitelerine göre yapı ruhsatı süreçleri bakımından değerlendirilmesi

\begin{tabular}{|c|c|c|c|c|c|}
\hline Belediye & Gerçekleștirilebilen Online İşlemler & $\begin{array}{l}\text { Yapı } \\
\text { Ruhsatı } \\
\text { Süresi } \\
\text { (Gün) }\end{array}$ & $\begin{array}{c}\text { Yapı } \\
\text { Kullanma } \\
\text { Izin } \\
\text { Belgesi } \\
\text { Süresi } \\
\text { (Gün) }\end{array}$ & $\begin{array}{l}\text { İstenen } \\
\text { Proje } \\
\text { Veri } \\
\text { Formati }\end{array}$ & $\begin{array}{c}3 B \text { Veri } \\
\text { Isteniyor Mu? }\end{array}$ \\
\hline Adalar & - & 60 & 90 & - & Hayır \\
\hline Arnavutköy & İmar Durumu Bilgisi Görüntüleme & 15 & - & - & Hayır \\
\hline Atașehir & İmar Durumu Bilgisi Görüntüleme & 7 & - & - & Hayır \\
\hline Avcllar & - & $20-30$ & 5 & - & Hayır \\
\hline Bağcılar & $\begin{array}{l}\text { İmar Durumu, İnşaat İstikamet ve Kot } \\
\text { Kesit Belgeleri Talepleri, Yapı Ruhsatı ve } \\
\text { Yapı Kullanma İzin Belgesi Bașvuruları }\end{array}$ & - & - & - & Hayır \\
\hline Bahçelievler & - & 20 & 15 & - & Hayır \\
\hline Bakırköy & - & 10 & 7 & - & Hayır \\
\hline Bașakșehir & - & 10 & 10 & - & Hayır \\
\hline Bayrampașa & - & - & - & - & Hayır \\
\hline Beşiktaş & İmar Durumu Bilgisi Görüntüleme & - & - & - & Hayır \\
\hline Beykoz & İmar Durumu Bilgisi Görüntüleme & - & - & - & Hayır \\
\hline Beylikdüzü & $\begin{array}{l}\text { İmar Durumu, İnșaat İstikamet ve Kot } \\
\text { Kesit Belgeleri Talepleri, Yapı Ruhsatı ve } \\
\text { Yapı Kullanma İzin Belgesi Başvuruları }\end{array}$ & - & - & - & Hayır \\
\hline Beyoğlu & - & - & - & - & Hayır \\
\hline Büyükçekmece & İmar Durumu Bilgisi Görüntüleme & - & - & - & Hayır \\
\hline Çatalca & - & - & - & - & Hayır \\
\hline Çekmeköy & İmar Durumu Bilgisi Görüntüleme & $10-30$ & 30 & - & Hayır \\
\hline Esenler & İmar Durumu Bilgisi Görüntüleme & - & - & - & Hayır \\
\hline Esenyurt & İmar Durumu Bilgisi Görüntüleme & 15 & 15 & - & Hayır \\
\hline Eyüpsultan & İmar Durumu Bilgisi Görüntüleme & - & - & - & Hayır \\
\hline Fatih & - & - & - & - & Hayır \\
\hline Gaziosmanpaşa & $\begin{array}{c}\text { İmar Durumu, İnşaat İstikamet ve Kot } \\
\text { Kesit Belgeleri Talepleri, Yapı Ruhsatı } \\
\text { Bașvurusu } \\
\end{array}$ & - & - & - & Hayır \\
\hline Güngören & - & 20 & 15 & - & Hayır \\
\hline Kadıköy & İmar Durumu Bilgisi Görüntüleme & 15 & $7-30$ & - & Hayır \\
\hline Kâğıthane & İmar Durumu Bilgisi Görüntüleme & - & - & - & Hayır \\
\hline Kartal & İmar Durumu Bilgisi Görüntüleme & - & - & - & Hayır \\
\hline Küçükçekmece & İmar Durumu Bilgisi Görüntüleme & - & - & - & Hayır \\
\hline Maltepe & İmar Durumu Bilgisi Görüntüleme & - & - & - & Hayır \\
\hline Pendik & $\begin{array}{c}\text { İmar Durumu, İnşaat İstikamet ve Kot } \\
\text { Kesit Belgeleri Talepleri, Yapı Ruhsatı } \\
\text { Bașvurusu }\end{array}$ & 30 & 10 & - & Hayır \\
\hline Sancaktepe & - & - & - & - & Hayır \\
\hline Sarıyer & - & - & - & - & Hayır \\
\hline Silivri & - & - & - & - & Hayır \\
\hline Sultanbeyli & İmar Durumu Bilgisi Görüntüleme & - & - & - & Hayır \\
\hline Sultangazi & İmar Durumu Bilgisi Görüntüleme & - & 15 & - & Hayır \\
\hline Şile & İmar Durumu Bilgisi Görüntüleme & - & - & - & Hayır \\
\hline Şișli & İmar Durumu Bilgisi Görüntüleme & 21 & - & - & Hayır \\
\hline Tuzla & İmar Durumu Bilgisi Görüntüleme & 14 & 3 & - & Hayır \\
\hline Ümraniye & İmar Durumu Bilgisi Görüntüleme & 15 & 7 & - & Hayır \\
\hline Üsküdar & İmar Durumu Bilgisi Görüntüleme & 15 & 30 & - & Hayır \\
\hline Zeytinburnu & - & - & - & - & Hayır \\
\hline
\end{tabular}

\section{TARTIŞMA VE ÖNERI}

$\mathrm{Bu}$ çalışmada kentlerin geçirdiği değişimde önemli rol oynayan inşa edilmiş çevrenin (built environment) bileșeni olarak inşa edilen yeni yapılara ait ruhsat süreçleri Türkiye'deki durumun iyileștirilmesine katkı sağlamak amacıyla değerlendirilmiştir. Yapı ruhsatı süreçlerinde 3B dijital yapı modellerinin kullanılmasının istenilen düzeyde olmadı̆̆ı görülmüştür. Yakın zamanda resmi gazetede yayımlanarak yürürlüğe giren "20202023 Ulusal Akıllı Şehirler Strateji ve Eylem Planı" içerisinde Türkiye'de dijital yapı modellerinin yapı ruhsatı süreçlerinde ve tesis yönetiminde kullanılmasına değinilmiştir. Bu gelişme 3B dijital yapı modellerinin kullanımıyla ilgili araştırmaların önemini arttırmaktadır. Dünya genelinde geleneksel yapı ruhsatı süreçlerinin yeteri kadar işlevsel ve 
şeffaf olmadığı görüşü hâkimdir. Bu nedenle sürecin otomatikleştirilmesi ve meydana çıkabilecek eksiklerin ortadan kaldırılması için inşaat ve tasarım dünyasında yaygın şekilde kullanılan BIM modellerinden faydalanılması etkin bir yol olarak görülmektedir (Mouloud et al., 2019).

Geleneksel yapı ruhsatı sürecinde yapının tasarımı 3B olarak BIM kullanılarak üretilmesine rağmen istenen proje belgeleri kâğıt çıtıları veya taratılmış PDF belgeleri olarak istenebilmektedir. Bu durum süreci sekteye uğratabilmektedir. Geleneksel sürecin ilerlemiş versiyonu ise yapı ruhsatı ve yapı kullanma izin belgesi başvurularının elektronik ortamda gerçekleștirilmesinden oluşmaktadır. Kamu hizmetlerinin dijitalleştirilmesinde amaçlanan hizmetlerden biri de yapı ruhsatı süreçlerinin elektronik ortamda gerçekleştirilmesidir. $\mathrm{AB}$ ülkeleri bu amaca ulașmak için somut adımlar atmakta ve ilerlemeler kaydetmektedir. Yine aynı şekilde Amerika Birleşik Devletleri (ABD) ve Kanada'da şehir yönetimleri yapı ruhsatı sürecinin elektronik olarak gerçekleştirilmesi için yeni projeleri hayata geçirmektedir (Shahi ark., 2019).

Dünyada BIM tabanlı olarak yapı ruhsatı sürecini 2000li yılların başında hayata geçiren ve yıllar geçtikçe geliştiren ülke Singapur'dur. Mevcut durumda diğer ülkelerinde ayak uydurmasiyla birlikte IFC formatlı dosyalar kullanılarak yapıların yönetmeliklere uygunluklarının otomatik olarak gerçekleștirilmesi amaçlanmakta bu da sürecin ilerlemiş bir diğer versiyonunu oluşturmaktadır (Nawari, 2018). Diğer önemli bir konu ise yönetmeliklerde belirtilen gürültü seviyesi ve yapının inşa edileceği parselin altında herhangi bir engelleyici yapı olup olmadığının tespiti gibi durumların sadece BIM ile anlaşılmasının oldukça zor olmasıyla ilişkilidir. Çünkü BIM, yapıları çok detaylı olarak semantik ve grafiksel açıdan modellemeye imkân sağlarken şu anki durumda kentler gibi büyük alanların modellenmesinde istenilen etkililiğe sahip değildir. Kentlerin modellenmesi için konumsal veri modellerinden faydalanılmaktadır. Günümüzde $3 \mathrm{~B}$ kent modellerinin oluşturulması için yaygin olarak kullanılan ve kabul görmüş standart CityGML'dir. Standart, farklı tematik alanlara sahip olarak kentlerin 3B modellenerek çeşitli uygulamalarda kullanılmalarına olanak tanımaktadır (Liu et al., 2017).

Akıllı șehirlerde gerçekleșen olaylara daha hızlı ve somut tepkiler verilebilmesi için ayrıntılı konumsal modellere ihtiyaç duyulmaktadır. Ancak bu şekilde inşa edilmiş çevrenin etkin şekilde yönetilebilmesi mümkün olmaktadır. Ĕger yapı ruhsatı süreçlerinde BIM modelleri kullanılırsa bu verilerin CityGML'e dönüștürülmesiyle 3B şehir modellerinin güncelliğinin sağlanmasına katkı verilebilir (Noardo et al., 2019). Son on yıllık süre içerisinde BIM ve CBS veri modellerinin arasındaki iki taraflı dönüşüm için çok fazla çaba sarf edilmiştir. Çünkü her iki modelleme ortamı da birbirlerine destek olucu birtakım özellikler barındırmaktadır.
Örneğin; CBS kullanılarak elde edilen geniş kapsama alanına sahip kent modelleri kullanıldığında yapıların çevrelerindeki diğer kent bileşenleriyle ilişkilerinin kurulabilmesi mümkün olmaktadır. Diğer yandan, BIM kullanılarak oluşturulan ayrıntılı yapı modelleri sayesinde kent modellerindeki yapıların daha yüksek detay seviyesinde ve daha gerçekçi olarak konumsal veri tabanlarında saklanabilmesi olanaklı olmaktadır. BIM ve CBS arasındaki dönüşüm araştırmaları genellikle IFC ve CityGML arasında gerçekleştirilmektedir. Bunun en önemli sebebi olarak bahsedilen iki standardın da yazılımdan bağımsız olmasıdır. Bu sayede farklı sistemler ve çalışma ortamları arasında birlikte çalışılabilirlik sağlanabilmektedir. Eğer belirli yazılımın kullandığı veri formatı kullanılarak dönüşüm yapilırsa bu durum format uyumsuzluğunu meydana getirecek ve uyumluluk sorunları oluşturabilecektir. Bununla birlikte farklı kullanıcılar tarafindan bu iki dosya formatının yaygın olarak kullanılması diğer bir etken olarak gösterilebilir (Deng et al., 2016).

Şimdiye kadar literatürde yer alan çalışmalar farklı metodolojiler ile IFC ve CityGML arasında tek taraflı veya iki taraflı dönüşümleri gerçekleştirmeye çalışmıştı ancak şu anda tam anlamıyla kesintisiz dönüşüme ulaşılamamıştır. Bu durumun en önemli sebeplerinden biri IFC'nin yapısal katı geometri (CSG) ve sinır betimleme (B-rep) modelleme anlayıșlarını desteklerken, CityGML'in sadece B-rep anlayıșıyla modellemeye imkân tanıması gösterilebilir. CityGML'in yakın zamanda yayımlanması beklenen yeni versiyonunda CSG modellemeye destek vereceği ön izleme sürümüyle birlikte öğrenilmiştir. Bu durum iki veri formatının daha nitelikli dönüşümüne destek olacaktır (Biljecki ve Tauscher, 2019). Yapıların yönetmeliğe uygunluğunun kontrolü BIM modellerinin CityGML formatına dönüştürülmesiyle de gerçekleștirilebilir. $\mathrm{Bu}$ sayede sadece uygunluk kontrolü elde edilmiş olmayacak aynı zamanda 3B ulusal konumsal veri tabanın da güncel tutulması sağlanabilecektir. Yapı ruhsatı verilmesinden sonra başlayan inșaat sürecinde yapının projesinde bazı değişiklikler meydana gelebilmektedir. $\mathrm{Bu}$ değişikliklerin yönetmeliğe uygunluğunun kontrolünün yapılması gerekmektedir. Bahsedilen süreçte IFC ve CityGML modellerinin kullanılması hem zaman hem de işlevsellik açısından fayda sağlayacaktır. İnşaatın tamamlanmasının ardından yapının inșa edilmiș halini temsil eden güncel uygulanmıș model (as-built model) elde edilmiş olacaktır. Bu aşamadan sonra arazi parselinde gerçekleşen cins değişikliğinin kadastro veri tabanına aktarılmasıyla mülkiyet haklarının güncel tutulması sağlanmaktadır (Atazadeh et al., 2019). 


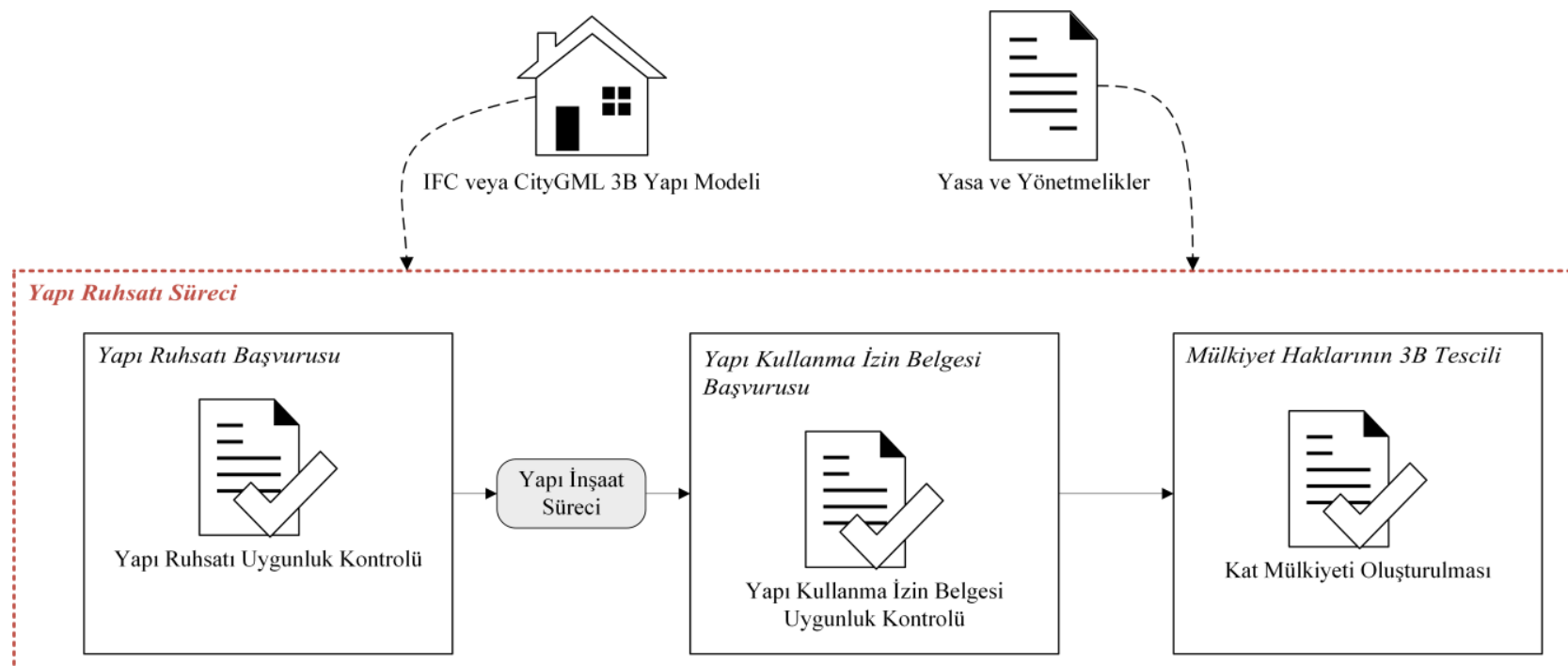

Şekil 10. Türkiye'deki yapı ruhsatı süreçlerine yönelik iyileştirici iş çerçevesi

2B çizimlerin ve grafik gösterimlerin karmaşık ve çok katmanlı yapılara sahip günümüz yaşam alanlarında mülkiyet haklarının sınırlarının betimlenmesinde yetersiz kaldıkları görülmektedir. $\mathrm{Bu}$ nedenle ortaya çlkan 3B kadastro kavramını gerçeğe dönüştürmek için önerilen çözümlerden biri taşınmaz üzerindeki sahiplik haklarının CityGML standardı kullanılarak modellenmesi olmuştur. Daha yakın zamanda mülkiyet haklarının ve fiziksel bileșenlerinin BIM modelleri kullanılarak 3B olarak kayıt altına alınması önerilmiştir (Atazadeh ark., 2017). Hollanda ve Avustralya'da IFC veri formatı kullanılarak taşınmazlarda paydaşların mülkiyet haklarının daha etkin şekilde yönetilebileceği örneklenmiștir. $\mathrm{Bu}$ durum yapı ruhsatı sürecinde kullanılan 3B tasarım modellerinden faydalanılmasıyla ortaya bütünleşik bir sistem önerisinin çıkmasını sağlamıștır (Oldfield et al., 2018). Tasarımcılar tarafindan oluşturulan gerçekçi ve detaylı 3B modellerin hem yapı ruhsatı süreçlerinde hem $3 \mathrm{~B}$ güncel konumsal veri tabanı tutulmasinda hem de 3B kadastro uygulamalarında kullanılabilmesi etkin bir iş sürecini mümkün kılmaktadır.

Çok sayıda yeni inşaatın gerçekleştiği Türkiye'de 3B modellerin yapı ruhsatı süreçlerinde kullanılması e-devlet dönüşümde Avrupa ülkeleri arasında istatistiklere göre ortalamanın üzerinde gelişmelere sahip mevcut sistemin daha da gelişmesine ve işlevsel hale getirilmesine olumlu katkı yapacaktır. Bunun yanı sıra tüm ülke kapsamında elde edilen 3B kent modellerinin güncel tutulması zaman ve ekonomik açıdan oldukça zor olmaktadır. Eğer yapı ruhsatı süreci sonucunda elde edilecek 3B yapı modelleri CityGML formatına dönüștürülüp konumsal veri tabanına aktarılabilirse neredeyse anlık olarak güncellik sağlanabilecektir. Diğer önemli bir konu ise köklü bir geçmişe sahip ülke kadastrosunun bulunduğu mevcut konumdan daha da ileri seviyeye getirilmesiyle ilgilidir. Tüm dünyada gerçekleştirilen 3B kadastro çalışmaları ışığında kat mülkiyeti kurulumlarının 3B yapı modellerinin gerekli birimlere iletilmesi ve mülkiyet haklarının doğru betimlendiğinin onaylanmasıyla kadastro veri tabanının güncel ve doğru tutulması sağlanabilecektir. Şekil 10 'da yapı ruhsatı süreçlerinin daha nitelikli hale getirilmesi için önerilen kavramsal iş akışı yer almaktadır. Şekilden de görülebileceği üzere yapı ruhsatı başvurusunun 3B dijital yapı modelleriyle gerçekleştirilmesi önerilmektedir. Yapı tasarımları çoğunlukla 3B olarak üretilmesine rağmen $2 \mathrm{~B}$ kâğıt çıktıları veya PDF belgeleri başvurularda kullanılmakta, mevcut detay seviyesinden faydalanılamamaktadır. Diğer bir önemli nokta ise dünyadaki otomatik yapı ruhsatı kontrolü çalışmalarından Türkiye'de de yararlanılması amacıyla yürürlükteki yasa ve yönetmeliklerin bilgisayarların anlayabileceği formata dönüștürülerek kontrol sürecinin otomatikleștirilmesidir. Kullanılan 3B dijital yapı modelleri inşaat sürecinde güncellenebilmektedir ve bu sayede uygulanan inşaata ilişkin gerçek model elde edilebilmektedir. Bu model kullanılarak 3B şehir modellerinin güncellenmesi mümkün olabilecektir. Gerekli dönüşümler yapıldıktan sonra arazi parselinde gerçekleşen dönüşüm dijital olarak kent veri tabanına aktarılabilecektir. Yapı kullanma izni alınmasından sonraki süreçte yapılardaki mülkiyet haklarının temsili yine bahsedilen uygulanmış modeller yardımıyla gerçekleștirilebilecektir. Böylelikle yeni inşa edilen binaların 3B kadastro uygulamaları için yeniden ölçülmelerine ve modellenmelerine gerek kalmayacak ve iş yükü açısından önemli bir fayda sağlanacaktır. 3B arazi idaresi dönüşümü için kadastral veri tabanlarının güncel tutulması büyük önem taşımaktadır. Bahsedilen yaklaşımla bu dönüşümün hayata geçirilmesine katkı verilebilir. 


\section{SONUÇLAR}

Gerçekleștirilen çalıșmada günümüzdeki karmaşık ve çok katmanlı birçok yeni yapının inşa edilmesiyle birlikte geleneksel yapı ruhsatı ve kat mülkiyeti süreçlerini daha işlevsel hale getirmek için uygulanabilecek bir iş akışı çerçevesi önerilmesi amaçlanmıştır (Şekil 10). Bu doğrultuda Türkiye'deki yapı ruhsatı süreçlerinin öncelikle çevrimiçi başvuru sistemine yönelik olarak geliştirilmesi ve ardından IFC veya CityGML gibi veri formatları kullanılarak proje dosyalarının sisteme yüklenip kontrol edilmeleri şeklinde bir planlama faydalı olabilecektir. Birçok önemli ve işlevsel edevlet projesini hayata geçirerek $A B$ ülkeleriyle karşılaştırıldığında kayda değer seviyeye ulaşılan Türkiye'de yapı ruhsatı süreçlerinin de daha etkin hale getirilmesiyle önemli ve sıkça kullanılan bir kamu hizmetinin üst düzey seviyeye çıkarılması sağlanabilecektir. $\mathrm{Bu}$ tür değişimler kullanıcılar tarafından iyi bir şekilde anlaşılmalı ve benimsenmelidir. Bunun sağlanması içinde farklı paydaşlarla iş birliği içinde olunması birlikte çalışılabilirliğin sağlanmasına katkı verecektir. Gerçekleştirilmesi gereken yasal düzenlemelerle sektörlerin yeni sürece uyum sağlaması daha hızlı sağlanabilir. $\mathrm{Bu}$ anlamda izlenecek yol haritası ülkelere göre farklılık gösterebilir. Bazı ülkeler için tepeden aşağı (top-down) yaklaşım daha etkili olabilmektedir. Bu yaklaşımda ilgili sektörler 3B yapı modellerini kullanmaya zorlanmaktadır ve bu şekilde ülkedeki sektörlerde köklü bir dönüşüm yaşanmaktadır. Bir diğer yaklaşımda ise AEC sektörü firmalarının yapı ruhsatı süreçlerinde dijital yapı modellerinin kullanılmasına ne kadar hazır oldukları incelenerek geçiş süreci bu bağlamda kurgulanmaktadır. Kat mülkiyeti süreçlerini daha etkili hale getirmek için BIM gibi kavramların kullanılması Dünya'da yeni araștırılan bir konudur. Türkiye'de bu konuyla ilgili fizibilite araștırmaları yapılması ve sürecin nasıl daha sağlıklı şekilde geliştirilebileceğinin anlaşılması ileriye dönük olarak büyük önem taşımaktadır. $\mathrm{Bu}$ anlamda gelecek çalıșmalarda Türkiye'de yapılara ait mülkiyet haklarının BIM ile 3B modellenmesi ve internet yardımıyla sunulması planlanmaktadır. Planlanan diğer bir çalışma ise önerilen yaklaşıma ilişkin olarak Türkiye'deki ilgili yasa ve yönetmeliklerin bilgisayarlar tarafından anlașılabilir formata dönüştürülerek yapı ruhsatı süreçlerinin otomatikleștirilmesine katkı sağlamaktır.

\section{BÍLGILLENDİRME/TEŞEKKÜR}

Bu makale İstanbul Teknik Üniversitesi (İTÜ) Geomatik Mühendisliği bölümünde yürütülen "Akıllı Kentlere Yönelik Kat Mülkiyeti Süreçlerinin Dinamik Yönetimi İçin CBS-Tabanlı Entegre Bir Modelin Geliştirilmesi (e-KATBİS)" başlıklı doktora tezinden üretilmiştir. Çalışma İTÜ Bilimsel Araştırma Projeleri Koordinasyon Birimince desteklenmiştir (Proje Numarası: MDK-2019-42092).

\section{KAYNAKÇA}

Aien, A., Kalantari, M., Rajabifard, A., Williamson, I. ve Bennett, R. (2013). Utilising data modelling to understand the structure of 3D cadastres. Journal of Spatial Science, 58(2), 215-234. https://doi.org/10.1080/14498596.2013.8013 30

Alkan, M. ve Polat, Z. A. (2017). Design and development of LADM-based infrastructure for Turkey. Survey Review, 49(356), 370-385. https://doi.org/10.1080/00396265.2016.1180 777

Atazadeh, B., Kalantari, M., Rajabifard, A. ve Ho, S. (2017). Modelling building ownership boundaries within BIM environment: A case study in Victoria, Australia. Computers, Environment and Urban Systems, 61, 24-38. https://doi.org/10.1016/j.compenvurbsys. 201 6.09.001

Atazadeh, B., Rajabifard, A., Zhang, Y. ve Barzegar, M. (2019). Querying 3D Cadastral Information from BIM Models. ISPRS International Journal of Geo-Information, $\quad 8(8), \quad 329$. https://doi.org/10.3390/ijgi8080329

Aydın, M. ve Yaman, H. (2018). Bina Enformasyonu Modellemesi (BIM) Tabanlı Bina Yönetmelik Uygunluk Kontrolü Literatürüne Genel Bir Bakış. Tasarım+ Kuram, 14(25), 59-77.

Bakici, T., Almirall, E. ve Wareham, J. (2013). A Smart City Initiative: The Case of Barcelona. Journal of the Knowledge Economy, 4(2), 135-148. https://doi.org/10.1007/s13132-012-0084-9

Biljecki, F ve Tauscher, H. (2019). Quality of BIM-GIS Conversion. ISPRS Ann. Photogramm. Remote Sens. Spatial Inf. Sci., IV-4/W8, 35-42. https://doi.org/10.5194/isprs-annals-IV-4W8-35-2019

Biljecki, Filip, Stoter, J., Ledoux, H., Zlatanova, S. ve Çöltekin, A. (2015). Applications of 3D City Models: State of the Art Review. ISPRS International Journal of Geo-Information, 4(4), 2842-2889.

https://doi.org/10.3390/ijgi4042842

BIMgenius. (2018). Türkiye BIM Raporu. https://www.bimgenius.org/uploads/6/3/9/9 /63997129/bImgenius_p0001_turkiye_bIm_ra poru_rev_1.pdf

Çağdaş, V. (2013). An application domain extension to citygml for immovable property taxation: A Turkish case study. International Journal of Applied Earth Observation and Geoinformation, 21(1), 545-555. 
https://doi.org/10.1016/j.jag.2012.07.013

Capgemini. (2007). The User Challenge Benchmarking The Supply of Online Public Services.

Commission of the European Communities. (2002). eEurope 2005: An information society for all.

Commission of the European Communities. (2006). i2010 eGovernment Action Plan: Accelerating eGovernment in Europe for the Benefit of All.

Deng, Y., Cheng, J. C. P. ve Anumba, C. (2016). Mapping between BIM and 3D GIS in different levels of detail using schema mediation and instance comparison. Automation in Construction, 67, 1-21. https://doi.org/10.1016/j.autcon.2016.03.006

Eriksson, Johansson, Olsson, Andersson, Engvall, Hast ve Harrie. (2020). Requirements, Development, and Evaluation of A National Building Standard-A Swedish Case Study. ISPRS International Journal of Geo-Information, 9(2). https://doi.org/10.3390/ijgi9020078

European Commission. (2016a). eGovernment Benchmark 2016. https://doi.org/10.2759/002688

European Commission. (2016b). EU eGovernment Action Plan 2016-2020.

Ho, S., Rajabifard, A., Stoter, J. ve Kalantari, M. (2013). Legal barriers to 3D cadastre implementation: What is the issue? Land Use Policy, 35, 379-387. https://doi.org/10.1016/j.landusepol.2013.06. 010

Kalogianni, E., van Oosteom, P., Dimopoulou, E. ve Lemmen, C. (2020). 3D Land Administration: A Review and a Future Vision in the Context of the Spatial Development Lifecycle. ISPRS International Journal of Geo-Information, 9(2), 107. https://doi.org/10.3390/ijgi9020107

Liu, X., Wang, X., Wright, G., Cheng, J., Li, X., Liu, R., Liu, X., Wang, X., Wright, G., Cheng, J. C. P., Li, X. ve Liu, R. (2017). A State-of-the-Art Review on the Integration of Building Information Modeling (BIM) and Geographic Information System (GIS). ISPRS International Journal of GeoInformation, 6(2), 53. https://doi.org/10.3390/ijgi6020053

Macit İlal, S. ve Günaydın, H. M. (2017). Computer representation of building codes for automated compliance checking. Automation in Construction, $\quad 82$, 43-58. https://doi.org/10.1016/j.autcon.2017.06.018
Macke, J., Rubim Sarate, J. A. ve de Atayde Moschen, S. (2019). Smart sustainable cities evaluation and sense of community. Journal of Cleaner Production, 239. https://doi.org/10.1016/j.jclepro.2019.11810

Malsane, S., Matthews, J., Lockley, S., Love, P. E. D. ve Greenwood, D. (2015). Development of an object model for automated compliance checking. Automation in Construction, 49(PA), 51-58.

https://doi.org/10.1016/j.autcon.2014.10.004

Meijer, F. ve Visscher, H. (2017). Quality control of constructions: European trends and developments. International Journal of Law in the Built Environment, 9(2), 143-161. https://doi.org/10.1108/IJLBE-02-2017-0003

Meijer, F., Visscher, H. ve Sheridan, L. (2002). Building regulations in Europe. DUP Science.

Mouloud, M., O., N. N. ve Ravi, S. (2019). Virtual Building Permitting Framework for the State of Florida: Data Collection and Analysis. Computing in Civil Engineering 2019, 328-335. https://doi.org/doi:10.1061/9780784482421. 042

Nawari, N. O. (2018). Building Information Modeling: Automated Code Checking and Compliance Processes. In Building Information Modeling (1st ed.). CRC Press. https://doi.org/10.1201/9781351200998

NBC. (2018). National BIM Report. https://www.thenbs.com/-

/media/uk/files/pdf/nbs-national-bim-report2018.pdf?la=en

Noardo, F., Ellul, C., Harrie, L., Overland, I., Shariat, M., Stoter, J. ve Arroyo Ohori, K. (2019). Opportunities and challenges for GeoBIM in Europe: developing a building permits use-case to raise awareness and examine technical interoperability challenges. Journal of Spatial Science, $1-25$. https://doi.org/10.1080/14498596.2019.1627 253

Oldfield, J., Bergs, R., Van Oosterom, P., Krijnen, T. ve Galano, M. (2018). 3D Cadastral Lifecycle: An Information Delivery Manual ISO 29481 for 3D Data Extraction from the Building Permit Application Process. 7th International FIG Workshop on the Land Administration Domain Model, 153-170.

Oldfield, J., Van Oosterom, P., Beetz, J. ve Krijnen, T. F. (2017). Working with open BIM standards to source legal spaces for a 3D cadastre. ISPRS 
International Journal of Geo-Information, 6(11). https://doi.org/10.3390/ijgi6110351

Olsson, P.-O., Axelsson, J., Hooper, M. ve Harrie, L. (2018). Automation of Building Permission by Integration of BIM and Geospatial Data. ISPRS International Journal of Geo-Information, 7(8), 307. https://doi.org/10.3390/ijgi7080307

Rajabifard, A. (2014). 3D Cadastres and Beyond. 4th International Workshop on 3D Cadastres.

Rajabifard, A., Atazadeh, B. ve Kalantari, M. (2018). A critical evaluation of 3D spatial information models for managing legal arrangements of multi-owned developments in Victoria, Australia. International Journal of Geographical Information Science, 32(10), 2098-2122. https://doi.org/10.1080/13658816.2018.1484 125

Shahi, K., McCabe, B. Y. ve Shahi, A. (2019). Framework for Automated Model-Based ePermitting System for Municipal Jurisdictions. Journal of Management in Engineering, 35(6), 04019025.

https://doi.org/10.1061/(asce)me.19435479.0000712

T.C. Resmi Gazete. (1965). Kat Mülkiyeti Kanunu. Sayı: 12038.

T.C. Resmi Gazete. (1985). İmar Kanunu. Sayı: 18749.

T.C. Resmi Gazete. (1987). Kadastro Kanunu. Sayı: 19512.

T.C. Resmi Gazete. (2001a). Türk Medeni Kanunu. Sayı: 24607.
T.C. Resmi Gazete. (2001b). Yapı Denetimi Hakkında Kanun. Sayl: 24461.

T.C. Resmi Gazete. (2005). Kadastro Kanununda Değişiklik Yapılması Hakkında Kanun. Sayı: 25744.

T.C. Resmi Gazete. (2017). Planlı Alanlar İmar Yönetmeliği. Sayı: 30113.

T.C. Resmi Gazete. (2018). Cumhurbaşkanlığı Teşkilatı Hakkında Cumhurbaşkanlığı Kararnamesi. Sayı: 30474.

T.C. Ulaştırma ve Altyapı Bakanlığı. (2016). 20162019 Ulusal e-Devlet Stratejisi ve Eylem Planı.

Teicholz, P., Lee, G., Eastman, C. ve Sachs, R. (2018). BIM Handbook: A Guide to Building Information Modeling for Owners, Designers, Engineers, Contractors, and Facility Managers (3rd ed.). John Wiley ve Sons, Inc.

Tekin, H. ve Atabay, Ş. (2019). Building information modelling roadmap strategy for Turkish construction sector. Proceedings of the Institution of Civil Engineers - Municipal Engineer, 172(3), 145-156. https://doi.org/10.1680/jmuen.17.00001

United Nations. (2018). E-Government Surveys. https://publicadministration.un.org/en/resear ch/un-e-government-surveys

Williamson, I., Rajabifard, A., Wallace, J. ve Bennett, R. (2011). Spatially Enabled Society. FIG Working Week 2011.

(C) Author(s) 2021. This work is distributed under https://creativecommons.org/licenses/by-sa/4.0/ 